\title{
Strategy for Development of Rice Sawah Culture Planting in Jarwo Plants with Various Modification of Plant Distance
}

\author{
Utami Paulina, Auzar Syarif, Aswaldi Anwar
}

Department of Agronomi, Faculty of Agriculture, Andalas University, Padang - West Sumatera, Indonesia

\begin{abstract}
Rice is the main food crop of the Indonesian population, mostly planted in paddy fields. The speed of population growth is not balanced with a decrease in rice production that occurs due to a decrease in harvested area. This research aims to determine the interaction between distance planting in the jarwo planting system on the growth and yields of lowland rice (oryza sativa). This research was conducted in December 2018 until March 2019 in Andalas Makmur, Parak Karakah, Kuranji District, Padang. The method used was a Randomized Block Design (RBD) with 2 factors governing spacing, consisting of 3 levels, namely J1: Distance planting (20 x 25) $\mathrm{cm}^{2}$, J2: Planting distance (25x 25) $\mathrm{cm}^{2}$, J3: Planting distance $(30 \times 25) \mathrm{cm}^{2}$, The second factor of the jarwo planting system consists of 4 levels, namely L1: Jajarlegowo 2: 1, L2 : Jajarlegowo 3: 1 A, L3: Jajarlegowo 3: 1 B, L4: Jajarlegowo 4: 1. In this experiment there were 12 combinations. Each combination consists of 3 groups. The observational data were statistically analyzed by the F test and if the F test count was greater than the F table of 5\%, then continued with Duncan's New Multiple Range Test (DNMRT) at the 5\% significance level. The results showed that there was no interaction between planting distances in various jarwo planting systems on growth and yields of paddy (oryza sativa).
\end{abstract}

Keywords-Rice, Spacing, Jajarlegowo.

\section{INTRODUCTION}

Rice is the main food crop of the Indonesian population, mostly planted in paddy fields. The speed of population growth is not balanced with a decrease in rice production that occurs due to a decrease in harvested area. Indonesia's food security, independence and sovereignty are not yet considered sturdy. This is indicated by high imports of food products. Until 2013 the problem of food security, especially rice, became a major problem for the Indonesian people. In 2011, imports were 1.6 million tons and in 2012 rice imports were 1.9 million tons (Pujiasmanto, 2013). In addition, the low productivity of rice is caused by the pattern of planting and harvesting of inter-regional wetland rice that is not uniform, agricultural technology innovation is still low, and land use is not yet optimal. The main problem of rice in cultivation is its stagnant productivity. In the past decade, the increase in rice yield per ha was not significant. Nationally, in 2011, productivity only reached around 5 tons per ha. On the other hand, the availability of paddy fields is also difficult to develop. Therefore, it is necessary to continue to look for cultivation methods that can increase yields and productivity.
The fundamental problem of food agriculture (rice) and is classic in Indonesia is narrow land, an average of 0.2-0.3 ha per farmer family. In the long history of agriculture, narrow land is not able to make farmers achieve economic and welfare levels. Indeed the government program has been able to increase rice production, but it is not always accompanied by improvements in farmers' welfare. One key to increasing production is through increasing productivity, while productivity cannot be separated from the role of agricultural technology.

As a staple food, rice cannot be replaced with other carbohydrate sources. That is because of the Indonesian people's eating habits, if you haven't eaten rice then it means you haven't eaten. Indonesian people's rice consumption based on the Central Statistics Agency in 2017 shows 1,571 / $\mathrm{kg} /$ week and 2017 rice production is 81.3 million tons / year (BPS, 2018). Over the past 37 years the average annual rice consumption is higher than the average annual rice production, therefore domestic rice production often does not cover domestic rice consumption (Kusmanaet., Al, 2017). 
According to Karokaroet al., (2014) in an effort to achieve the government's target of increasing national rice production $(\mathrm{P} 2 \mathrm{BN})$ in this case the Ministry of Agriculture through development and research agencies has issued many recommendations to be applied by farmers. One of these recommendations is the application of a correct and good planting system through spacing of planting known as the jajarlegowo planting system. In principle, the jajarlegowo planting system is to increase the population by adjusting the spacing. This planting system also manipulates the layout of the plants, so that most of the clumps of plants become edge plants (Ikhwani et al. 2013).

Jarwo planting system is structuring rice plants by adjusting the spacing in such a way as to achieve optimal plant population and the number of plants that get more side effects than the usual planting method, so as to produce higher productivity than conventional planting methods. This has been proven by farmers who apply well, rice farming with the Jarwo planting system on average is able to increase rice productivity.

Some obstacles in applying the Jarwo planting system are as follows: The application of the Jarwo planting system is not correct, which is seen from the lower number of plant populations compared to conventional systems / tiles so that productivity is not significantly different or lower than conventional planting methods, planting power is scarce, while in the other side of the Jarwo system requires more expensive planting costs, there is a slash system where traders value the yield of production per ha is not different between the Jarwo system and the tiled system so that farmers do not get incentives to implement the Jarwo planting system, and planting a single seed in the Jarwo planting system also farmers are still doubtful because farmers are accustomed to planting 2-3 seeds per hole.

Furthermore according to (Santoso et al., 2005) several factors that cause the development of legowo row planting are not: (1) a wholesale planting system that requires faster planting time, while the legowo planting system requires a longer time; (2) the limited number of planting workers skilled in the application of the Legowo planting method, and (3) the higher the Legowo planting costs.

But what we need to know about the use of plant spacing is basically to give the possibility of plants to grow well without experiencing much competition in terms of taking water, nutrients, and sunlight. Proper spacing is important in optimizing the use of sunlight for photosynthesis. In the right planting distance, plants will get a balanced growth space. The effect of the rice planting system as a component of cultivation that has an effect on yield and income, is apparently complex (Makarim et al. 2005). Plant spacing and plant orientation in the field affect the following six important processes: (1) capturing solar radiation by plants for photosynthesis, (2) absorption of nutrients by the roots, (3) plant water requirements, (4) circulation of photosynthetic $\mathrm{CO} 2$ and $\mathrm{O} 2$ resulting from photosynthesis, ( $5)$ availability of space that determines weed populations, and (6) microclimate under the canopy, which influences the development of plant pests (OPT). The results of spacing in Indonesia reported Pratiwi et al. (2010) concluded that wide spacing provides opportunities for plant varieties to express their growth potential. The denser the plant population, the smaller the number of tillers and the number of panicles per clump. In low populations (wide spacing), the performance of large rice groves, but the breadth of yield and yield components is lower than denser spacing.

The right spacing will give maximum growth, number of tillers, and yields. According to Sohel et al. (2009), the optimum spacing will provide good growth of the top of the plant so that it can utilize more sunlight and the growth of the roots which is also good so that it can utilize more nutrients. Conversely, planting spacing that is too tight will result in very intense competition between plants in terms of sunlight, water, and nutrients. As a result, plant growth is inhibited and crop yields are low.

To overcome these obstacles, the Government is making efforts to re-highlight the way rice cultivation is highlighted and appointed as one of the breakthroughs in increasing rice productivity, namely the jajarlegowo planting system. Legowo row rice planting system is one of the cultivation techniques that can provide opportunities for rice plants to provide various facilities including ease in application of fertilizer, weed control and control of plant pests.

Orientation of legowo row cropping although in the same population has the opportunity to produce higher grain because of the more photosynthesis that occurs, because it is more effective in capturing solar radiation and the easy diffusion of CO2 gas for photosynthesis. Lin et al. (2009), states that wide spacing can improve total light capture by plants and can increase seed yield. Greater distance between rows can improve the total light radiation captured by plants and can increase yields.

Therefore, the application of the Legowo row planting system in accordance with local environmental conditions will almost certainly increase rice productivity and profits for farmers, while national expansion can increase rice production. Legowo planting system 2: 1 or $3: 1$ and 4: 1 , is 
an alternative technology component in irrigated rice. The choice of Integrated Plant Management (PTT) technology component is based on the identification of the area and the problems of rice farming which are expected to be an opportunity to overcome the problem of doubling rice productivity (Basri, et. Al. 2010). Peripheral plants grow and develop better and yields per clump are higher than those in the middle, so that more and more border effect edge crops in rice fields produce more grain. For that reason, in terms of increasing rice production, it is highly recommended to use the Legowo row planting system. Because, the components of rice yield (apart from being determined by the type of variety and yield level) are significantly affected by spacing, especially the amount of grain and panicle length (Pratiwi et al., 2009). This spacing is regulated not only to regulate plant neatness but also to be used as populations or clumps, so as to overcome the problem of rice productivity, it is necessary to have a new technology and innovation in agricultural production, namely by using new spacing patterns, namely the legowo row system in rice cultivation.

\section{RESEARCH METHODS}

A. Time and Place This research took the form of a field trial, which was carried out from December 2018 to March 2019 in Andalas Makmur, ParakKarakah, Kuranji District, Padang. The schedule of activities can be seen in Appendix 1.

\section{B. Materials and Tools}

The materials used in the research are IR 42 Varieties of Rice Seeds (description can be seen in Appendix 2), raffia ropes, manure, NPK 15 inorganic fertilizers, Urea, and insecticides for pest control (darmabas and ribcorde). The tools used in this experiment were plow, machete, rake, seed bed, hoe, meter, calipers, scales, scythe, $15 \mathrm{~L}$ sprayer and stationery.

\section{Research Design}

This research was in the form of a factorial 2-factor experiment that was designed according to a randomized group (RBD). The first factor is spacing which consists of 3 levels, namely:

PP1: Spacing $(20 \times 25) \mathrm{cm}^{2}$

PP 2: Spacing $(25 \times 25) \mathrm{cm}^{2}$

PP3: Spacing $(30 \times 25) \mathrm{cm}^{2}$

The second factor is the jarwo planting system which consists of 4 levels, namely:
L1: Jajarlegowo 2: 1

L2: Jajarlegowo 3: 1 A

L3: Jajarlegowo 3: 1 B

L4: Jajarlegowo 4: 1

The layout of the experimental plot is in Appendix 5 and the plant population and samples in each experiment per plot are in Appendix 4. In this experiment there are 12 treatment combinations. Each combination consists of 3 groups so that there are 36 total experimental units. The observational data were statistically analyzed by the F test and if the F test count was greater than the $\mathrm{F}$ table of $5 \%$, then continued with Duncan's New Multiple Range Test (DNMRT) at the 5\% significance level.

\section{RESEARCH IMPLEMENTATION}

\section{A. Land Preparation}

Land preparation begins with plowing twice, the first is to use a tractor by turning the soil over and flooded during processing. The second hijacking is done a week after the first hijacking, and when the second hijacking is done at the same time as the ground smearing. A few days after puddling the soil was leveled and mapped 36 plots of $3 \times 4 \mathrm{~m}$ in size and $0.75 \mathrm{~m}$ in spacing between groups in $1 \mathrm{~m}$.

\section{B. Nursery}

The nursery is carried out in the experimental field with $2 \mathrm{x}$ $1 \mathrm{~m}$ seedling size. The varieties planted in this study are IR 42. Preparation for the nursery is carried out; (1) Rice seed selection is by inserting rice seeds into a bucket that has been filled with water, (2) Floating seeds are discarded and seeds that are immersed are soaked for $2 \times 24$ hours and air dried for 12 hours until they germinate. (3) Germinated seeds are sown at the nursery for 21 days.

\section{Labeling}

Labeling is done after making the test plot according to the treatment, the label is made of plastic label.

\section{Planting}

The age of the seeds of rice plants used is 21 days after seedling (HSS). Planting was carried out simultaneously for all treatments with 3 stems per planting hole. Spacing and planting systems are adjusted according to the treatment. The distance of the plants is $20 \times 25 \mathrm{~cm}, 25 \times 25 \mathrm{~cm}$ and $30 \times 25 \mathrm{~cm}$ with each jarwo different types, namely $2: 1,3: 1 \mathrm{~A}, 3: 1 \mathrm{~B}$, and 4: 1 . 
E. Maintenance

Maintenance carried out include:

E.a. Stitching

This stitching is done by using seeds planted outside the ranks of the Legowo ranks. These seeds are planted simultaneously with planting in the fields. Planted seedlings are given a distance of $10 \mathrm{~cm}$ from plants that have been planted. It is intended that if the main seedlings in the row die because the snail pest is kept then the seedlings will be replaced by enlarging into the ranks. The seeds used for replanting come from early peace. Replanting is done no later than 7 days after planting

\section{E.b. Weeding weeds}

Weed weeding is done a week after planting until the end of the vegetative period with a interval of once a week. Weeding is done when weed populations grow in the study area according to conditions in the field. Weed weeding is done manually by pulling weeds in the study area, which was flooded first to make it easier to weed.

\section{E.c. Fertilization}

Fertilization is done by sowing. Fertilization of empty rows between 2 rows of plants. Fertilizer is sown to the left and right evenly, so that in one go can fertilize two rows of plants. Fertilization is done using Urea Fertilizer with a recommendation of $250 \mathrm{~kg} / \mathrm{ha}$, which is done 2 weeks after planting and 5 weeks after planting, SP $36100 \mathrm{~kg} /$ ha which is done at the age of 5 weeks after planting and andKCl $100 \mathrm{~kg} /$ ha is done at 5 weeks after planting (Appendix 3).

\section{F. Harvesting}

Harvesting is done when the rice plants have yellowed more than $90 \%$ in one plant family and the leaves have dried, namely when the rice plant is 18 MST. Harvesting is done by mowing the rice plants using a sickle, after which threshing is done to separate the rice grain.

\section{A. Plant height $(\mathrm{cm})$}

Observations were made by measuring plants from the base of the stem (root neck) to the longest leaves in the sample plants using a meter. Observation starts 2 weeks after planting to 8 weeks after planting with an observation interval of 2 weeks.

B. Total Number of Puppies (clumps)

Observation of the number of tillers per clump in the sample plants began 2 weeks after planting to 8 weeks after planting with an observation interval of 2 weeks. The number of tillers was calculated by counting all the stems per plant.

\section{RESULTS AND DISCUSSION}

A. Plant height $(\mathrm{cm})$

The height of rice plants at the age of 8 MST did not have a significant effect and there was no interaction between the treatment of spacing and jarwo planting patterns (Appendix 7.D). Rice plant height data can be seen in table 4 :

Table 4. The height of a jarwo paddy cropping plant with various spacing and jarwo planting system:

\begin{tabular}{llllll}
\hline \multirow{2}{*}{$\begin{array}{l}\text { JarakTanam } \\
(\mathrm{cm})\end{array}$} & \multicolumn{3}{l}{ JajarLegowa } & \multicolumn{2}{l}{$\begin{array}{l}\text { Rata } \\
\text { rata }\end{array}$} \\
\cline { 2 - 5 } & $2: 1$ & $3: 1 \mathrm{~A}$ & $3: 1 \mathrm{~B}$ & $4: 1$ & $\mathrm{~cm}$ \\
\hline $20 \times 25$ & 89,27 & 89,67 & 84,20 & 69,00 & 87,71 \\
$25 \times 25$ & 86,73 & 93,07 & 89,60 & 81,53 & 89,80 \\
$30 \times 25$ & 84,73 & 84,00 & 82,87 & 91,80 & 83,87 \\
\hline Rata - rata & 86,91 & 88,91 & 85,55 & 80,77 & \\
\hline KK : 10,12\% & & & & & \\
\hline
\end{tabular}

Note: the figures on the lane and are not significantly different according to the $\mathrm{F}$ test at 5\% significance level.

Based on the results of the calculation of variance shows that the treatment of the use of spacing in the planting system jajarlegowo pattern is not significantly different and there is no interaction between the two factors. This is seen from a distance. This is because the jajarlegowo planting system provides wider space so that competition does not occur between plants to get a greater supply of nutrients so that it affects growth and production.

Spacing that is not too tight causes sunlight to enter the planting area which can then be used by plants for photosynthesis. The more plants absorb sunlight will accelerate the process of photosynthesis, as well as the formation of photosynthates so that the filling of grain will be optimal (Supriyanto et al., 2010). 


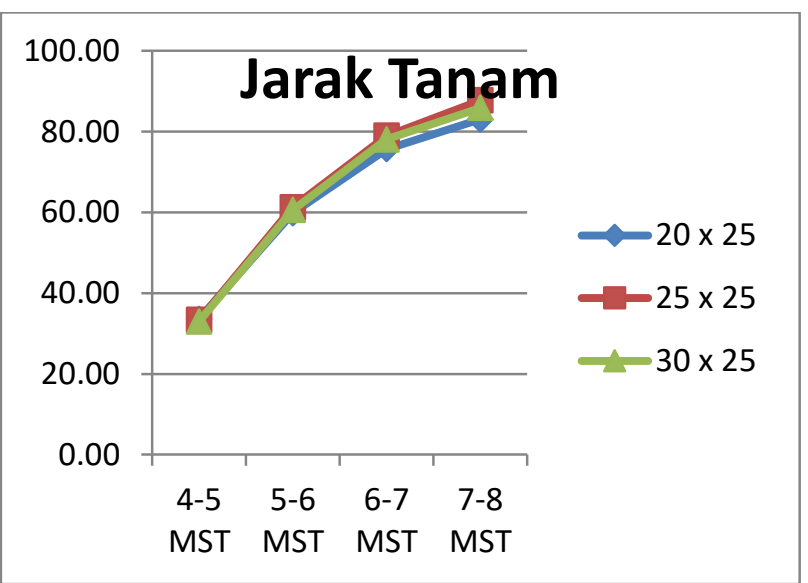

Plant height graph for spacing treatment

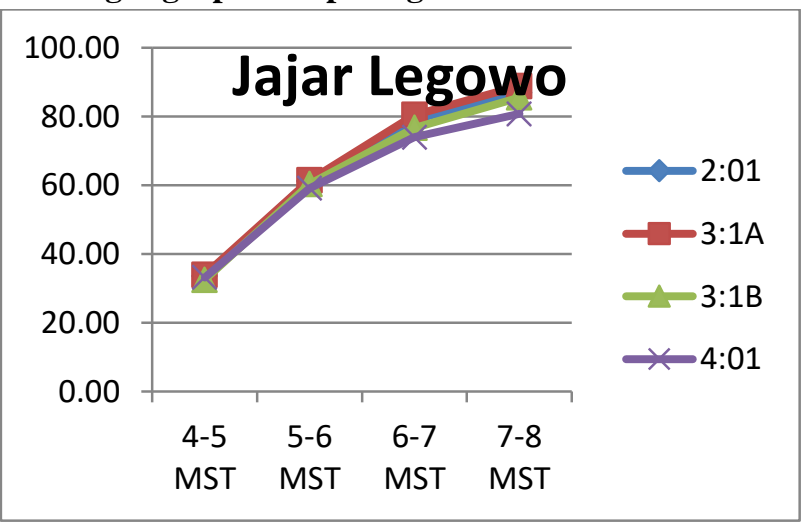

Plant height chart in the treatment of Legowo row

Fig.4: Development of plant height in jarwo wetland rice cultivation with various modifications of spacing

Based on Figure 4 on the plant height chart we can see that the value of development every week on the height of rice plants in the distance plant treatment is increasing every week as well as in the treatment of the Legowo row type where the increase occurs every week.

In accordance with the opinion of Aribawa (2012), it states that a higher plant height is produced in more plant populations in one stretch. High plant growth does not guarantee crop productivity is also high. Plants that grow well are able to absorb nutrients in large quantities, the availability of nutrients in the soil affects the activity of plants including photosynthetic activity, so that the plant can increase growth and production. The more the distance of planting is used, the higher plant growth will be faster because the plants are trying to find more sunlight (Nursanti, 2009).

Here can be seen in table 4, namely jarwo 4: 1 cropping pattern with a spacing of $30 \times 25 \mathrm{~cm}$ which is the lowest average value, This is because the growth of rice plants is more influenced by population density. At high densities competition will occur against sunlight, oxygen, nutrients and water. According to Bozorjai (2011) where the high and low rice plants are strongly influenced by the level of plant density.

Muyasir (2012) states that the increase in plant height is caused by the plant's canopy which is getting closer together resulting in the quality of the light received being decreased. The closer plant spacing is used, the higher plant growth will be faster because the plants try to look for more sunlight. In the treatment of plant spacing, rice plants are not able to develop more rapidly due to high plant density. The ability of seeds to obtain nutrients still experiences competition with the use of tight spacing. According to Mulyaningsihet. al (2008). Competition is a form of relationship between two or more individuals having a negative influence on both parties. Because basically the use of the legowo network system is an effort to increase rice production / yield by manipulating the environment, so as if all plants are peripheral plants, so that the utilization of sunlight can be optimized for photosynthesis. This is in accordance with the opinion of Ikhwani, Gagad, Eman and Makarim (2013), the use of plant spacing is basically giving the possibility of plants to grow well without experiencing much competition in terms of fetching water, nutrients, and sunlight. The right planting distance is important in the optimal utilization of sunlight for photosynthesis. In the right planting distance, plants will get a balanced growth space.

B. Total Number of Puppies (sticks)

The total number of tillers at the age of 8 MST showed no significant influence and interaction between treatment of plant spacing and jarwo system planting patterns (Appendix 7.E). Data on the total number of tillers is shown in table 5 .

Table 5. Total number of tillers of jarwo planting patterns with various spacing and jarwo planting systems:

\begin{tabular}{llllll}
\hline \multirow{2}{*}{$\begin{array}{c}\text { JarakTanam } \\
(\mathrm{cm})\end{array}$} & \multicolumn{2}{c}{ JajarLegowa } & & & Rata \\
& $2: 1$ & $3:$ & $3: 1 \mathrm{~B}$ & $4: 1$ & - rata \\
\hline $20 \times 25$ & 39,27 & 38,67 & 35,73 & 35,07 & 37,89 \\
$25 \times 25$ & 34,73 & 39,60 & 36,87 & 34,53 & 37,07 \\
$30 \times 25$ & 36,07 & 33,53 & 35,53 & 36,87 & 35,04 \\
\hline Rata - rata & 36,69 & 37,26 & 36,04 & 35,49 & \\
\hline KK $: 10,78 \%$ & & & & & \\
\hline
\end{tabular}

KK : $10,78 \%$

Note: the figures on the lane and are not significantly different according to the $\mathrm{F}$ test at 5\% significance level. 
Based on the results of the calculation of variance shows that the treatment of the use of spacing with several planting systems jarwo pattern is not significantly different. This is seen in the table we see that there is no interaction between the two treatment factors. This is expected because the number of plant rows and plant populations are not too large and dense, so that the optimal environmental conditions can be used when growing.

Sauki et al. (2014), the maximum number of tillers will affect the number of productive tillers and correlate to the results.

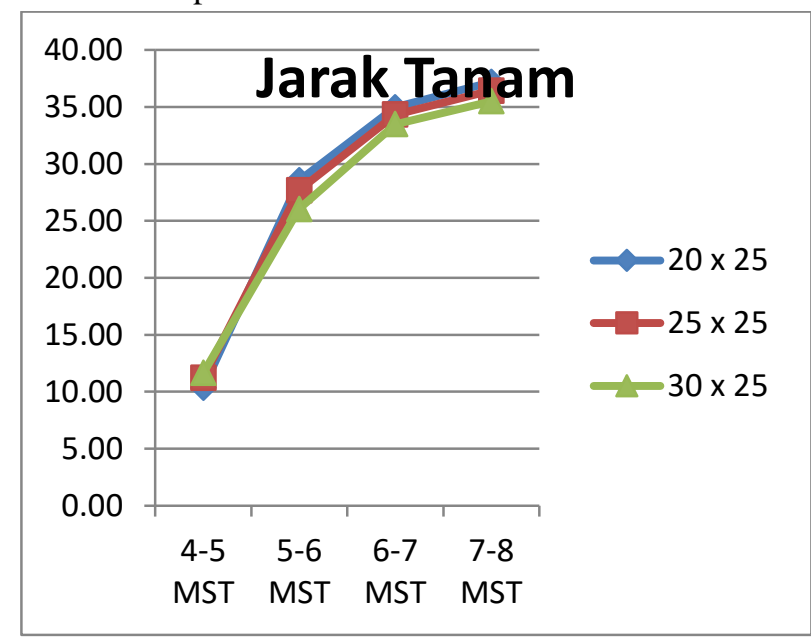

Graph of total number of tillers in spacing

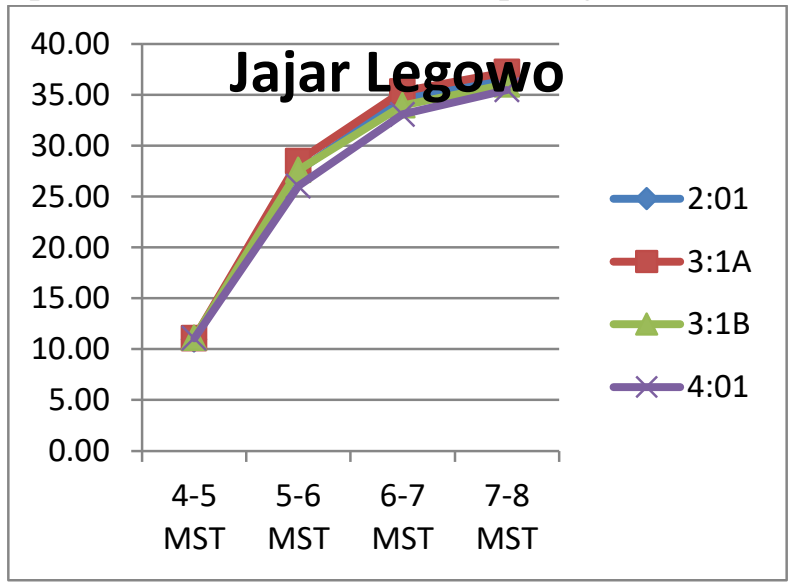

Graph of total number of tillers in spacing

Fig.5. The development of the total number of tillers in jarwo paddy rice cultivation with various modifications to planting

spacing

Based on Figure 5 in the graph the total number of tillers we can see that the value of development every week the number of tillers in rice plant spacing increases every week as well as in the treatment of Legowo row type where an increase occurs every week.
This is related according to Husana (2010), the number of tillers will be maximal if the plant has good genetic traits added with favorable environmental conditions or in accordance with plant growth and development.

Furthermore, it was stated that the maximum number of tillers was also determined by spacing, because spacing determined solar radiation, mineral nutrients and cultivation of the plant itself. But genetic and environmental factors also determine the productivity of rice.

Proper spacing is important in optimizing the use of sunlight for photosynthesis, to obtain a balanced growth space. With the occurrence of competition, especially water and unclean elements will disrupt plant growth. The application of the jarwo planting system is able to assist plants in photosynthesis optimally, the existence of an empty space in the form of an aisle that extends the legowo planting system will increase the interception of light and co2 into the crop then it will also increase plant metabolism and biosistesis so that the production of rice plants is more optimal. Increasing the number of rice seedlings every week occurs because young seedlings have better adaptability compared to old seedlings so plants can grow better. Age of seedlings in the field moved very influential on rice production. The faster the field seedlings move, the more adequate the period for seedlings to adapt to the new environment, so the more adequate period for seedling and root development. In addition, the number of rice tillers is also related to the phyllochron formation period. Phyllochron is the period in which a set of stems, leaves and roots emerge from the base of the plant and the subsequent germination. The older the seedlings are moved to the field, the fewer the number of phyllochron produced, while the younger the seedlings are transferred, the more the number of phyllochron produced so that the number of tillers can be produced (Sunadi, 2008).

Unlike the 4: 1 jarwo planting pattern with a spacing of $30 \times 25 \mathrm{~cm}$ which results in the least number of tillers. This is suspected because the legowo row planting system is a manipulation of the layout of a plant so that the plantations will have a higher number of edge plants in the presence of an empty row. Although the use of a number of seedlings per planting hole will not have an effect because population densities still occur, so they are not optimal in receiving sunlight.

Besides the influence of population density on the planting system, the formation of tillers is also influenced by genetic traits and environmental conditions that are in accordance with plant growth. According to Asfaruddin (1997) tall plants 
use more asimilatnya for the formation of stems and leaves than for the formation of tillers.

A wider spacing allows each plant to get more resources so that plant growth and productivity are better. According to Uphoff et al., (2002) that the number of tillers will be maximal if soil fertility and growth space are optimal. The wider spacing between lines in the Legowo range makes it easier to regulate water and control pests and plant diseases and maximize utilization of fertilization. The number of tillers in rice plants does not increase with age as the plant enters the generative phase. The more total number of tillers produced will potentially produce the number of productive tillers.

\section{CONCLUSIONS AND RECOMMENDATIONS}

Conclusions

There is no interaction between plant spacing in various jarwo planting systems on the growth and yield of lowland rice

\section{Suggestions}

Based on the results of the study and conclusions obtained, it is recommended that when conducting research on plant spacing and jarwo cropping system, use the right spacing is not too tight and not too tenuous so that the use of spacing gives the possibility of plants to grow well without experiencing much competition, besides that in the jarwo planting system use the appropriate method of planting the system so that plant growth will be optimal.

\section{REFERENCES}

[1] Aribawa, 2012.Effect of cropping systems on increasing rice productivity in wetlands upland wetlands.Bali Institute of Agricultural Technology Assessment (BPTP).Denpasar.Http:// universitas.trunojoyo.ac.id.

[2] Asfaruddin, 1997.Evaluation of upland rice galenggalur tolerability of aluminum poisoning and its efficiency in the use of potassium. Thesis. IPB graduate program. Bogor. Central Bureau of Statistics .2018.Rice Production in Entire Provinces. http://bps.tnmnpgn.go.id. Accessed July 2, 2018.

[3] Basri, F. and Haris M., 2010. Fundamentals of International Economics: Introduction and Application of Quantitative Methods. Kencana: Jakarta.

[4] Husana, Y. 2010. Effect of Use of Spacing on Rice Growth and Production. Thesis. Agriculture Science Study Program Post Graduate Program.Tadulako University. Ikhwani, Pratiwi, Paturrahman, and Makarim, (2013) 'Increased rice productivity through the application of spacing jajarlegowo', Food Crops Science, 8 (2): 72-79.
[5] Karokaro, S., J. E. Rogi, D. S. Runtunuwu, and P. Tumewu. 2014. Spacing of Rice Paddy Planting (Oryza sativa L.) in LegowoJajar Planting System. [Online].Www.portalgaruda.com.Accessed January 23, 2017.

[6] Kusmana A, Budiman A, Hidayat A. 2017. Development of Food Production and Consumption in Indonesia.https: //mpra.ub.unimuenchen.de. Accessed on 2 July 2018.

[7] Lin, XQ, D.F. Zhu, H.Z. Chen, and Y.P. Zhang 2009.Effects of plant density and nitrogen application rates on grain yield and nitrogen uptake of super hybrid rice. Rice Science 16 (2): 138-142.

[8] Makarim, A.K., D. Pasaribu, Z. Zaini, and I. Las. 2005. Analysis and synthesis of the development of integrated crop management models for lowland rice. Indonesian Rice Research Institute. 18p.

[9] Mulyaningsih, 2008.Comparative Analysis of Income of SRI (System of Rice Intensification) with the Conventional System.Faculty of Agriculture.University of Lampung.

[10] Muyassir 2012.Effect of Spacing, Age and Number of Seedlings on Yields of Rice (Oryza sativa L.). J. Land Resource Management. 1 (2): 207-212.

[11] Nursanti, R. 2009. Effect of Seed Age and Planting Distance on Growth and Productivity of Hotong (Setaria italic (L.)Beauv) Crops. Journal of Plant Production.5 (2): 52:54.

[12] Pratiwi, G.R., E. Suhartatik, and A.K. Makarim 2010.Productivity and yield components of rice as a function of plant population. In: S. Abdulrachman, H.M. Toha, and A. Gani (Eds.). Rice Technology Innovation to Maintain SelfSufficiency and Encourage Rice Export.National Seminar Proceeding on Rice Research Results 2009, Book 2.Indonesian Center for Rice Research.p.443-450.

[13] Pujiasmanto, 2013. Strengthen our national food security. Professor of the Faculty of Agriculture, SebelasMaret University (UNS).Surakarta http://www.uns.ac.id. Sauki A, Nugroho. A and Soelistyono.E, 2014.The Effect of Spacing and Inundation on the Sri (System of Rice Intensification) Method on Growth and Yield of Rice (Oryzasativa.L.).Journal of Plant Production, Volume 2, Number 2, March 2014, p.121127.

[14] Supriyanto E., E Syakiroh J., and Wisnu A. 2010.The effect of the legowo planting system and the concentration of liquid supplementary fertilizers on rice growth and production. Biofarm Agricultural Scientific Journal, 13 (8).

[15] Sohel M. A. T., M. A. B. Siddique, M. Asaduzzaman, M. N. Alam, \& M.M. Karim, 2009. Varietal Performance of Transplant Safe Rice Under Diff [e] rent Hill Densities. Bangladesh J. Agril. Res. 34 (1): 33 - 39. Accessed July 25, 2011.

[16] Uphoff, N. 2002.Presentation for C on Raising Agricultural Productivity in the Tropics. Biophysical Challenges For Technology And Policy; The System Of Rice Intensification Developed In Madagascar. 8 things. 